\title{
HUBUNGAN ANTARA EFIKASI DIRI DAN KEMAMPUAN BERPIKIR KRITIS MATEMATIKA SISWA
}

\author{
Imaludin Agus \\ Institut Agama Islam Negeri Kendari, Jln. Sultan Qaimuddin No.17,Kendari \\ imaludinagus@iainkendari.ac.id
}

\begin{abstract}
Received:

This article aims to analyze the relationship between self-efficacy and critical

06/06/2020 thinking skills of junior high school students in mathematics. This research was conducted in class VIII with a total of 56 students in the Sub-district of Kontukowuna. The type of research used is correlation description with the sample

Accepted :

$03 / 11 / 2020$ selected by random sampling. The instruments in this study consisted of 4 items of critical thinking skills test instruments and 25 items of non-self-efficacy tests. Data collected were analyzed using descriptive correlation. The results showed

Published : that there was a positive relationship between self-efficacy and critical thinking

21/01/2021 skills of junior high school students in mathematics with a correlation value (0.62). That is, the higher the students' self-efficacy, the higher their critical thinking abilities.
\end{abstract}

Keywords: critical thinking, self-efficacy, mathematics

\begin{abstract}
Abstrak
Artikel ini bertujuan untuk menganalisis hubungan efikasi diri dan kemampuan berpikir kritis siswa SMP pada mata pelajaran matematika. Penelitian ini dilaksanakan pada kelas VIII dengan jumlah 56 siswa di Kecamatan Kontukowuna. Jenis penelitian yang digunakan adalah korelasi deskripsi dengan sampel dipilih secara random sampling. Instrumen dalam penelitian ini terdiri atas instrumen tes kemampuan berpikir kritis sebanyak 4 soal dan non tes efikasi diri sebanyak 25 item. Data yang dikumpulkan dianalisis menggunakan deskriptif korelasi. Hasil penelitian menunjukan bahwa terdapat hubungan yang positif antara efikasi diri dan kemampuan berpikir kritis siswa SMP pada mata pelajaran matematika dengan nilai korelasi $(0,62)$. Artinya, semakin tinggi efikasi diri siswa maka kemampuan berpikir kritisnya semakin tinggi pula.
\end{abstract}

Kata Kunci: Berpikir Kritis, Efikasi Diri, Matematika

\section{Pendahuluan}

Matematika merupakan mata pelajaran penting yang harus dipelajari siswa disemua jenjang pendidikan. Sebagaimana, amanat yang tertuang dalam Undang-Undang Nomor 20 Tahun 2003 tentang Sistem Pendidikan Nasional Pasal 37 Ayat 1 menyatakan bahwa pembelajaran matematika menjadi matapelajaran wajib di ajarkan kepada siswa mulai dari sekolah dasar maupun menengah. Hal ini dikarenakan matematika memiliki peranan bagi peningkatan Ilmu Pengetahuan dan Teknologi Informasi. Selain itu, pembelajaran matematika membekali siswa untuk berpikir kritis, kreatif dan inovatif sehingga mampu menyelesaikan masalah disekitarnya (Peraturan Menteri Pendidikan dan Kebudayaan Republik Indonesia Nomor 21 Tahun 2016 tentang standar isi pendidikan dasar dan menengah). 
Memperhatikan pentingnya mata pelajaran matematika dalam mengakomodir kemampuan berpikir siswa, maka proses pembelajaran matematika harus berorentasi peningkatan kemampuan berpikir. Salah satu kemampuan berpikir yang harus dioptimalkan adalah kemampuan berpikir kritis. Kemampuan berpikir kritis merupakan kemampuan mengambil kesimpulan secara tepat (Agus, 2019, 120). Selain itu, berpikir kritis diartikan sebagai pemikirian yang masuk akal, sehingga mampu memutuskan sebuah kebenaran (Ennis, 2011, 1). Lebih lanjut, Gambrill (2005, 11-12) berpikir kritis merupakan proses evaluasi yang hati-hati terhadap setiap pendapat sebagai dasar pertimbangan untuk mengambil keputusan yang lebih baik.

Ciri seseorang telah memiliki kemampuan berpikir kritis menurut Lau $(2011,2)$ yaitu mereka mampu memahami hubungan antara ide, merumuskan ide, mengidentifikasi, mengkonstruksi dan mengevaluasi setiap argumen/pendapat. Selain itu, Feldman $(2010,21)$ ciri pemikir kritis diindikasi melalui kemampuan mereka yang dapat melihat titik putih diwarna yang gelap. Olehnya itu, seseorang yang telah memiliki kemampuan berpikir kritis diasumsikan mampu secara kritis menyelesaikan setiap persoalan dalam kehidupannya.

Merujuk pada urgensi kemampuan berpikir kritis dimiliki oleh setiap orang tanpa terkecuali siswa, maka kemampuan ini harus diinjeksikan kepada mereka. Namun, fakta yang terjadi saat ini, kemampuan berpikir kritis siswa khususnya siswa SMP belum diakomodir secara baik. Hal ini didasarkan hasil pada hasil studi yang dilakukan oleh Trends International Mathematics and Science Study (TIMSS) tahun 2015 yang menempatkan negara Indonesia urutan ke 44 dari 49 negara yang berpartisipasi. Selain itu, jika ditinjau dari dari level soal matematika TIMSS tahun 2011, kemampuan siswa Indonesia hanya dominan pada level pengetahuan dan penerapan, sedangkan level berpikir hanya $1 \%$ siswa menjawab benar (Hadi \& Novaliyosi, 2019, 562-569). Hasil ini didukung pula oleh studi yang dilakukan Programe for International Student Assesmant (PISA) khususnya kemampuan matematika siswa mengalami penurunan sebanyak 7 poin yaitu pada tahun 2015 sebesar 386 menurun menjadi 379 pada tahun 2018 (OECD, 2019).

Menyikapi kondisi tersebut, maka peningkatan kemampuan berpikir kritis siswa menjadi tugas besar yang harus dilakukan. Untuk itu, maka peninjauan aspek pendukung menjadi sebuah alternatif yang dapat dilakukan. Aspek pendukung kemampuan berpikir kritis yang dimaksud adalah faktor kepribadian. Menurut Hoffman dan Reiss (2009) salah satu faktor kepribadian yang berperan penting adalah efikasi diri. Demikian pula Slavin (2014) menyatakan bahwa efikasi diri merupakan variabel penting yang harus dimiliki 
oleh siswa, sebab mereka yang memiliki efikasi diri cenderung menggunakan strategi belajar kognitif. Efikasi diri diartikan sebagai keyakinan diri atas kemampuan yang dimiliki sehingga mampu untuk bertindak yang diwujudkan melalui kinerja (Bandura, 2009). Senada dengan itu, Liu dan Koirala (2009) efikasi diri merupakan keyakinan siswa tehadap kemampuan, keberhasilan, dan kegigihan mereka didalam belajar serta menyelesaikan tugas matematika.

Efikasi diri menurut Bandura (2009) terdiri atas tiga dimensi yaitu magnitude, strenght, dan generality. Magnitude, adalah dimensi yang berhubungan dengan tingkat kesulitan dalam menghadapi suatu masalah. Dalam konteks ini, siswa akan cenderung memilih tugas-tugas yang sulit dibandingkan yang mudah. Strength, adalah kekuatan yang mengacu pada ketegasan dan keyakinan individu dalam melakukan sesuatu dengan kemampuan yang dimiliki. Sedangkan, generality adalah keyakinan atas keberhasilan dan kegagalan seseorang.

Berdasarkan pemaparan tersebut bahwa kemampuan berpikir kritis dapat diakomodir/dimiliki oleh siswa dengan didukung oleh faktor kepribadian yang salah satunya adalah efikasi diri. Hal ini dukung oleh penelitian yang dilakukan oleh Sundari, Parno, \& Kusairi (2016), dan Azizah \& Nurjanam (2018) yang menyebutkan bahwa kemampuan berpikir kritis, serta Aprisal \& Arifin (2020), meyatakan pula bahwa penaralan matematika memiliki korelasi dengan efikasi diri siswa. Meskipun penelitian tentang ini sudah sering dilakukan, namun dalam penelitian ini karateristik siswa cenderung memiliki efikasi diri yang rendah. Hal ini terindikasi melalui ketidakyakinan siswa dalam menyelesaikan tugas-tugas matematika dengan tingkat kesulitan yang tinggi serta ketidakyakinan siswa terhadap jawaban matematika yang dikerjakan. Selain itu, subjek dalam penelitian ini belum pernah menjadi subjek penelitian yang berkaitan dengan efikasi diri dan kemampuan berpikir kritis. Dengan demikian pada penelitian ini akan memaparkan tentang hubungan antara efikasi diri dan kemampuan berpikir kritis matematika siswa SMP.

\section{Metode Penelitian}

Penelitian ini merupakan penelitian deskriptif korelasi yang bertujuan untuk melihat hubungan antara efikasi diri dan kemampuan berpikir kritis matematika siswa. Subjek dalam penelitian ini sebanyak 56 siswa kelas VIII SMPN di Kontukowuna Kecamatan. Kontukowuna Kabupaten. Muna Provinsi. Sulawesi Tenggara. Penelitian 
dilakukan sebanyak dua kali tes yaitu tes kemampuan berpikir kritis matematika siswa dan efikasi diri.

Instrumen tes kemampuan berpikir kritis terdiri atas empat butir soal uraian materi bangun ruang yang didasarkan pada indikator kemampuan berpikir kritis yaitu interpretasi, evaluasi, analisis, dan inferensi. Sedangkan, instrumen efikasi diri terdiri atas 24 butir soal non tes yang merujuk pada tiga dimensi efikasi diri yaitu magnitude, strenght, dan generality. Instrumen non tes menggunakan skala likert disajikan pada tabel 1 berikut:

Tabel 1. Skala Likert

\begin{tabular}{lcc}
\hline \multicolumn{1}{c}{ Skala Likert } & Positif & Negatif \\
\hline Selalu (S) & 5 & 1 \\
Sering (SR) & 4 & 2 \\
Kadang-Kadang (K) & 3 & 3 \\
Jarang (J) & 2 & 4 \\
Tidak Pernah & 1 & 5 \\
\hline
\end{tabular}

Kedua instrumen tersebut sebelum digunakan terlebih dahulu dilakukan validitas isi oleh ahli dan reliabilitas. Untuk mengukur korelasi kedua variabel tersebut digunakan formula pearson product moment. Jika signifikasi uji korelasi $<0,05$ maka terdapat hubungan antara efikasi diri dan kemampuan berpikir kritis matematika siswa.

\section{Hasil dan Pembahasan}

Hasil pada penelitian ingin menunjukan seberapa besar hubungan antara efikasi diri dengan kemampuan berpikir siswa SMP. Analasis korelasi dilakukan pada kedua variabel tersebut dengan menggunakan bantuan IBM SPSS 21. Adapun hasil analisis korelasi disajikan pada tabel 2 berikut:

Tabel 2. Korelasi Efikasi Diri dan Kemampuan Berpikir Kritis Siswa

\begin{tabular}{ccc}
\hline Jumlah Siswa & Pearson Correlation & Sig \\
\hline 56 & 0,62 & 0,00 \\
\hline
\end{tabular}

Berdasarkan tabel 2, diperoleh hasil korelasi sebesar 0,62 dengan nilai signifikansi $0,00<0,05$. Artinya bahwa terdapat hubungan yang kuat antara efikasi diri dengan kemampuan berpikir kritis siswa. Dari hasil analisis korelasi pula diperoleh koefisien korelasi positif yang berarti bahwa terdapat hubungan yang searah antara efikasi diri dan kemampuan berpikir kritis. Jika efikasi diri siswa baik maka berdampak pada kemampuan berpikir kritisnya juga baik, begitupula sebaliknya. Sebagaimana, Fahmi \& Mauziraji (2013) menyatakan bahwa dengan meningkatkan keyakinan diri maka akan berdampak 
pada kepercayaan diri dalam belajar, mengerjakan tugas, aktif, serta mampu berpikir secara kritis.

Seseorang yang memiliki kemampuan berpikir kritis cenderung mampu mempertimbangan setiap keputusan yang akan diambil sehingga dapat menarik kesimpulan secara tepat. Secara spesifik didalam pembelajaran matematika, berpikir kritis diperlukan agar mampu menyelesaikan masalah matematika yang tidak rutin. Untuk itu, diperlukan efikasi diri yang kuat agar setiap keputusan sesuai dengan yang diharapkan. Sebagaimana, Bandura (2009) menyatakan bahwa efikasi diri (keyakinan diri) menentukan bagaimana setiap orang berfikir, berprilaku, dan memotifasi dirinya. Bertalian dengan itu, Rohaeti, Hindun, \& Fitriani (2019), menyatakan bahwa efikasi diri sangat mempengaruhi seseorang dalam membuat keputusan dan pola pikirnya. Lebih lanjut, dalam pembelajaran matematika, siswa dengan efikasi diri yang tinggi mampu menyelesaikan masalah matematika yang kompleks serta mampu menyelesaikan tugastugas matematika yang membutuhkan kemampuan berpikir. Bahkan, Hoffman (2009) salah satu faktor yang mempengaruhi kemampuan berpikir kritis adalah faktor kepribadian yang diantaranya efikasi diri.

Hal ini didukung pula oleh penelitian Sundari, Parno, \& Kusairi (2016), serta Azizah \& Nurjanam (2018) yang menyatakan bahwa terdapat hubungan yang positif antara efikasi diri dan kemampuan berpikir kritis. Begitu pula, Slavin (2014) menyatakan bahwa efikasi diri merupakan variabel penting yang harus dimiliki oleh siswa, sebab mereka yang memiliki efikasi diri cenderung menggunakan strategi belajar kognitif, sehingga mendukung peningkatan kemampuan berpikir kritis. Senada dengan ini, Liu dan Koirala (2009) menyatakan bahwa orang yang memiliki efikasi diri yang tinggi cenderung memiliki kekuatan dan kegigihan dalam menyelesaikan suatu tugas.

\section{Kesimpulan}

Berdasarkan hasil penelitian disimpulkan bahwa terdapat hubungan yang positif antara efikasi diri dan kemampuan berpikir kritis matematika siswa SMP $\mathrm{N}$ Kontukowuna. Dimana, semakin tinggi efikasi diri siswa maka semakin tinggi pula kemampuan berpikir kritisnya.

\section{Pustaka}

Agus, I. (2019). Efektivitas guided discovery menggunakan pendekatan kontekstual ditinjau dari kemampuan berpikir kritis, prestasi, dan self-efficacy. Jurnal Riset 
Pendidikan Matematika,

$6(2)$

$120-132$.

doi:https://doi.org/10.21831/jrpm.v6i2.14517

Aprisal \& Arifin, S. (2020). Kemampuan Penalaran Matematika Dan Self-Efficacy Siswa SMP. DELTA-Jurnal Ilmiah Pendidikan Matematika, 8(1), 31-40. Doi: http://dx.doi.org/10.31941/delta.v8i1.945.

Bandura, A. (2009). Self-efficacy in changing societies. Cambridge: Cambridge University Pres.

Ennis, R. H. (2011). The Natural of Critical Thinking: An Outline of Critical Thingking Disposition and Abilities. Sixth International Conference on Thinking at MIT.

Fahmi, M \& Mauziraji, A, N. (2013). The Relationship between Iranian EFL Students' Self-efficacy Beliefs and Critical Thinking Ability. Theory and Practice in Language Studies, 3(3), 538-543. Doi: 10.4304/tpls.3.3.538-543

Feldman, D. (2010). Berpikir Kritis Starategi Pengambilan Keputusan. Jakarta: PT Indeks.

Gambrill, E. (2005). Critical Thinking in Clinical Practice in Clinical Practice of Judgments and Decisions (2th ed). New York: John Wiley \& Sons.

Hadi, S \& Novaliyosi. (2019). TIMSS Indonesia. Prosiding Seminar Nasional, 562-569.

Hoffman, L. L., Hutchinson, C. J. \& Reiss, E. (2009). On improving school climate: Reducing reliance on rewards and punishment. International Journal of Whole Schooling, 5(1). Savannah: Armstrong Atlantic State University.

Lau, J. Y. F. (2011). An introduction to critical thinking and creativity: Think more, think better. John Wiley \& Sons.

Liu, X., \& Koirala, H. (2009). The effect of mathematics self-efficacy on mathematics achievement of high school students. NERA Conference Proceedings 2009, 30. https://opencommons.uconn.edu/nera_2009/30.

Nurazizah, S., \& Nurjaman, A. (2018). Analisis Hubungan Self Efficacy terhadap Kemampuan Berpikir Kritis Matematis Siswa pada Materi Lingkaran. JPMIJurnal Pembelajaran Matematika Inovatif, 1 (3), 361-370.

OECD. (2019). PISA 2018 Result. www.oecd.org/about/publishing/corrigenda.htm.

Peraturan Menteri Pendidikan dan Kebudayaan Republik Indonesia Nomor 21 Tahun 2016 tentang standar isi pendidikan dasar dan menengah, (2016).

Rohaeti, E, E., Hindun, S., \& Fitriani, N. (2019). Correlation of self-efficacy and mathematical critical thinking skills based on student's cognitive stage. Journal of Physics: Conf. Series 1315 (2019) 012034. Doi: 10.1088/1742$6596 / 1315 / 1 / 012034$

Slavin, R. E. (2014). Educational psychology: Theory and practice. Pearson College Div. 
Sundari, P. D., Parno, \& Kusairi, S. (2016). Hubungan antara efikasi-diri dan kemampuan berpikir kritis siswa. Makalah dipresentasikan pada Seminar Nasional Pendidikan IPA Pascasarjana UM. Malang.

Undang-Undang Nomor 20 Tahun 2003 tentang Sistem Pendidikan Nasional, (2003). 

Vol. 9 No. 1 Januari 2021 hal. $1-8$ 